\title{
Cardamom and oral health
}

Sir,

Cardamom, which is also known as the "queen of spices", is one of the most widely known spices due to its strong aroma and flavor. Cardamom is the dried, unripened fruit of the perennial plant species "Elettaria cardamomum". Enclosed in the fruit pods are tiny, brown, aromatic seeds, which are both pungent and sweet to the taste..$^{[1]}$ In Indian sub continent, it is one of the most culinary spices. This warm spice has been in use since ancient times in China, India, Korea and Vietnam for improving digestion. Both in middle east and India, it is used for flavoring hot beverages such as tea and coffee as well as sweets. However, the most common use of cardamom in India has been as an excellent breath freshner and is an integral part of betel quid.

It is also invaluable for its medicinal properties. Cardamom is said to be loaded with a variety of health promoting nutrients such as calcium, iron, phosphorous, volatile oil (cineole), flavonoids, and ether extracts. ${ }^{[2]}$

The seed contains a volatile oil. The principal constituents of the volatile oil are cineol, terpinene, limonene, sabinene, and terpineol in the form of formic and acetic acid. Cineole a major component of cardimum oil is an antiseptic that can kill bad breath bacteria and various others. ${ }^{[3]}$

A study by Cohen et al. concluded indicate that cardamom flavoured chewing gum are effective in reducing the negative affect associated with nicotine withdrawal and may serve as a valuable tool in helping smokers quit. ${ }^{[4]}$

Oral health is extremely important and cardamom is very beneficial in maintaining it. Aneja and Radhika ${ }^{[5]}$ conducted a study on the antimicrobial action of cardimum on the dental caries causing micro organisms. The study concluded that the cardimum extracts showed antimicrobial activity against oral pathogens like streptococci mutans and Candida albicans. Apart from this, its slightly pungent but pleasant taste stimulates salivary flow. Thus there is a strong possibility that cardimum can be used as a caries preventive agent.
Though, there is a growing amount of in-vitro research identifying cardimums potential and oral health benefit, but, further in vivo studies are required to explore the possibilities of cardimum in oral health.

Shailee Fotedar, Vikas Fotedar ${ }^{1}$

Department of Public Health Dentistry,

H. P. Government Dental College, ${ }^{1}$ Department of Radiation Oncology, Regional Cancer Center, Indira Gandhi Medical College, Shimla, Himachal Pradesh, India

\author{
Address for correspondence: \\ Dr. Shailee Fotedar, \\ Department of Public Health Dentistry, \\ H. P. Government Dental College and Hospital, \\ Shimla, Himachal Pradesh, India. \\ E-mail:drfotedar@rediffmail.com
}

\section{REFERENCES}

1. Health benefits of cardamom. Available from: http://www. steadyhealth.com/health_benefits_of_cardamom.html. [Last accessed on 2013 Jan 12].

2. Peter KV. Hand book on spices and herbs. Available from: http:// www.pars.itvhe.ac.ir/_fars/Documents/2001-29001.pdf. [Last accessed on 2013 Jan 14].

3. Bakhru HK. Herbsthat heal: Natural remedies for good health-Page53 - Google Books Result. Available from: http://www. books.google.co.in/books?isbn. [Last accessed on 2013 Jan 17].

4. Cohen LM, Collins FL Jr, Vanderveen JW, Weaver CC. The effect of chewing gum flavor on the negative affect associated with tobacco abstinence among dependent cigarette smokers. Addict Behav 2010;35:955-60.

5. Aneja KR, Radhika J. Antimicrobial activity of amomum subulatum and Elettaria cardamomum against dental caries causing microorganisms. Ethnobotanical Lealf 2009;13:840-9.

\begin{tabular}{|l|l|}
\hline \multicolumn{2}{|c|}{ Access this article online } \\
\hline Quick Response Code: & Website: \\
\hline & www.ejgd.org \\
\hline & \\
\hline
\end{tabular}

